Part I

Overviews

(1) 


\section{Extraterritorial Immigration Control: What Role for Legal Guarantees?}

Bernard Ryan

\section{Introduction}

The immigration control systems of developed states are today frequently characterised by strategies of 'extraterritorialisation'. This has involved the rejection of the model whereby admission decisions are taken at ports and border crossing points, and the policing of irregular migration takes place either at the borders or within the territory. Developed states now increasingly treat that model as anachronistic, and seek instead to take immigration control action - both decisionmaking and enforcement - prior to an individual's arrival on their territory. In some cases, indeed, the objective appears to be that as much immigration control activity as possible should take place elsewhere, either on the territory of other states, or in international waters, where the presumption is that states lack jurisdiction.

This chapter provides an overview, from a legal perspective, of extraterritorial practices within contemporary immigration control. It will focus on examples from the United States, the United Kingdom and the European Union, with the experiences of other developed states referred to where appropriate. The material is organised into three substantive sections, which discuss visa requirements, predeparture checks and interception at sea, respectively.

The chapter's starting-point is Guiraudon's observation that extraterritorialisation strategies aim at "short-circuiting judicial constraints on migration control." 1 The chapter will show that the development of extraterritorial immigration control techniques typically reflects a mixture of non-legal and legal factors. Non-legal factors include passenger convenience, the prevention of irregular migration, security, and the terms of the relationship with specific other states. The legal element consists in the avoidance of international law and domestic law

\footnotetext{
${ }^{1}$ Virginie Guiraudon, "Before the EU Border: Remote Control of the 'Huddled Masses', in In Search of Europe's Borders, ed. Kees Groenendijk, Elspeth Guild and Paul Minderhoud (The Hague, Kluwer: 2002), 194.
} 
guarantees, including both substantive rights and procedural avenues for legal challenge. By way of conclusion, the chapter will reflect on the normative basis for the restoration of legal guarantees in a context of continued extraterritorial immigration control.

\section{Visa requirements}

The initial sense of the term 'visa' was the endorsement of a travel document by a state official, in order to signify that they had 'seen' the document, in a context where the forms of travel document varied widely. Torpey has shown that general requirements upon travellers to obtain visas in this sense go back to at least the early nineteenth century in Europe. ${ }^{2}$ At that time, visa requirements typically applied to all travellers, irrespective of nationality, and applied to travel within countries as well as between them. Gradually, visa requirements came to acquire a second function: no longer mere endorsements, but rather a form of permission which an individual must obtain before arrival at a state's ports of entry. Visa requirements, aimed specifically at controlling admission to states arose with the establishment of an inter-state passport system in the late nineteenth century. An early example was Germany's visa requirement upon those arriving from Russia between 1879 and 1894, the purpose of which was to limit migration by ethnic Poles. ${ }^{3}$ Another early case was the United States law of 1884 which required returning migrants from China - who were exempt from new Chinese exclusion laws - to have their passports endorsed by US officials in the port of departure, in order to confirm their status. ${ }^{4}$

The First World War was decisive in the move to more general visa regimes: once introduced, they generally continued after they war, unless modified by reciprocal arrangements. ${ }^{5}$ The international visa regime was further developed in the 1930s, as a result of refugee flows associated with Nazi Germany's policies, particularly after the Anschluss with Austria in March 1938, the annexation of the Sudetenland in October 1938 and the Kristallnacht pogroms of November 1938. The events of 1938 led potential destination states to use visa restrictions both to limit numbers and to select those least likely to impose financial costs

2 John Torpey, The Invention of the Passport: Surveillance, Citizenship and the State (Cambridge, Cambridge University Press: 2000), Chapter 3.

3 Ibid, 108-110.

${ }^{4}$ Ibid, 98-99.

5 Ibid, 116-117. 
upon them. The result was that, by early 1939, among possible destinations, only the open city of Shanghai did not require a visa. ${ }^{6}$

In the postwar era, visa requirements have been commonplace within immigration control regimes. In order to understand contemporary visa systems, this section contains a discussion of the position in the United States, United Kingdom and (more briefly) the European Union.

\section{United States}

The United States first introduced a visa requirement in July 1917, soon after its entry into World War I. ${ }^{7}$ A legislative basis for this requirement was given by an Act of May 1918 concerning entry and exit from its territory, ${ }^{8}$ and a visa requirement was retained after the war came to an end. ${ }^{9}$ The next major development was the introduction of a generalised visa regime for intending permanent migrants (known as 'immigrants' in the United States system) by the Immigration Act of $1924 .{ }^{10}$ The background was that national origins quotas had been introduced for permanent immigration by legislation in 1921, but proved unworkable without a system of entry permits, since passengers risked being refused entry upon arrival once the corresponding quota was exhausted. Accordingly, the 1924 legislation made the possession of a valid visa a precondition to admission for all permanent immigrants. ${ }^{11}$ Its effect was that negative decisions - because a quota had been reached, or for other reasons, such as an individual's medical condition or that they were thought "likely to become a public charge" - took place

${ }^{6}$ Alfred Sherman, Island Refuge: Britain and Refugees from the Third Reich (London: Paul Elek, 1973), 209. The United Kingdom introduced visa requirements for Austrian and German nationals in April 1938, and for Czechoslovak nationals in April 1939: ibid, 88-90, 158 and 271.

7 "Joint Order of the Department of State and Department of Labor" (26 July 1917), reprinted in Immigration and Naturalization Law and Issues: A Documentary History, ed. Michael LeMay and Elliott Barkan (Westport, Greenwood: 1999), 113-115.

8 Act of 22 May 1918, 65 Public Laws 154. Based on this power, a visa requirement was set out in Executive Order 2932 "Prescribing Rules and Regulations on the Issuing of Permits to Enter and Leave the United States" (8 August 1918), section 31, reprinted in American Journal of International Law Supplement 12 (1918): 331.

9 Act making appropriations for the Diplomatic and Consular Service (2 March 1921, 66 Public Laws 357), discussed in Leon Wildes, "Review of Visa Denials: The Consular Officer as 20th Century Absolute Monarch” San Diego Law Review 26 (1989): 887, 893-894.

10 Discussed by Torpey, ibid, 119-120 and Aristide Zolberg, 'The Great Wall Against China: Responses to the First Immigration Crisis, 1885-1935' in Migration, Migration History, History, ed. Jan Lucassen and Leo Lucassen (Berne, Peter Lang: 1997), 308-309.

11 Immigration Act 1924, sections 2 and 13. 
mainly at points of departure rather than points of arrival. Temporary visitors ('non-immigrants') meanwhile remained subject to the rules deriving from the 1918 Act. $^{12}$

The principle that all non-citizens require a visa in order to be admitted to the territory is now reflected in the Immigration and Nationality Act 1952..$^{13}$ There are exceptions for journeys from certain adjacent territories - including Canada and Bermuda, but not Mexico - by nationals of those territories. ${ }^{14}$ Since the Immigration Reform and Control Act 1986, the United States has also had a 'visa waiver program' (VWP), which permits individuals to stay in the United States for up to 90 days for tourist or business purposes. At the time of writing, 35 countries are covered by the VWP, including 22 EU member states. ${ }^{15}$

The most recent reform of the US visa system is that, since 12 January 2009, the 'Electronic System for Travel Authorisation' (ESTA) has been added to the VWP. ${ }^{16}$ Under ESTA, intending VWP travellers must obtain advance electronic approval for travel to the United States. Passenger details are checked against terrorist and criminal watch lists, information on lost and stolen passports, and information on previous visa revocations. If approval is refused, the individual is required to apply for a visa, despite their VWP nationality. While no sanction is specified for not obtaining ESTA approval, an individual without it will presumably be denied boarding by a carrier, and would anyway face a refusal of admission should they succeed in reaching a United States port of entry.

The mixture of immigration and security factors shaping the visa regime can be seen in the strict conditions for states' eligibility for the VWP. ${ }^{17}$ These include a low rate of refusal of temporary visas to nationals (less than $3 \%$ in the previous year), that participating states report both lost and stolen passports to the United States or Interpol, and that they share intelligence on individuals who might be a threat to the US. ${ }^{18}$ Paradoxically, the existence of the VWP is thought to enhance security, because it gives the United States leverage over the forms of document

\footnotetext{
12 Executive Order 4125 of 12 January 1925, discussed in United States ex rel London v. Phelps 22 F.2d 288 (Court of Appeals, 1 November 1927).

138 USCA 1182 (a)(7).

148 Code of Federal Regulations (CFR) 212.1.

15 The VWP covers all EU members except Bulgaria, Cyprus, Greece, Poland and Romania. Seven non-EU European states are within the VWP: Andorra, Liechtenstein, Iceland, Monaco, Norway, San Marino and Switzerland. The other six VWP states are Australia, Brunei, Japan, New Zealand, Singapore and South Korea.

${ }_{16}$ For details, see Alison Siskin, Visa Waiver Program, Congressional Research Service Report RL 32221, 30 January 2009, 5-6 and Department of Homeland Security, 'Changes to the Visa Waiver Program To Implement the Electronic System for Travel Authorization (ESTA) Program' Federal Register 73 (111), 9 June 2008.

${ }_{17}$ For a summary of policy the VWP, see Siskin, 1-14.

18 The main conditions are set out in 8 USCA 1187.
} 
issued by participating states. Since 27 October 2005, VWP nationals have had 2 to present machine-readable passports, while participating states have been required to issue passports with biometric identifiers. In practice, irregular migration concerns are often decisive in the loss of VWP status, as when the fear of overstaying led to its withdrawal from Argentina (2001) and Uruguay (2003), after economic crises in those countries.

While the US visa system was initially developed for practical reasons, at a time of long-distance sea travel, legal factors have also been significant throughout its history. This is because, since the 1920s, US courts have taken the view that consular decisions to refuse visas are not reviewable by the courts. ${ }^{19}$ They have done so both out of deference to the Congressional prerogative power over immigration, and because of a statement in the Immigration and Nationality Act precluding the Secretary of State from supervision of consular decisions over visas. ${ }^{20}$ The one exception is that judicial review is possible where a visa refusal affects constitutional rights, such as freedom of expression ${ }^{21}$ or the rights concerning family life. ${ }^{22}$ By contrast, where a foreign national is refused admission at a United States port of entry, the default position is that they are entitled to review of any removal by an immigration judge. ${ }^{23}$ One exception is that, where a refusal of admission is due to the non-possession of required documents, or document fraud, removal without appeal is permitted ('expedited removal'). ${ }^{24}$ A second exception is that entry under the VWP is conditional upon the individual's waiving any legal claims against a decision of inadmissibility or removal. ${ }^{25}$ Even in these two cases, however, it remains possible to claim asylum within a removal procedure. ${ }^{26}$

19 The early decisions are those of the Courts of Appeals in United States ex rel London v. Phelps 22

${ }^{21}$ The authority for this is the Supreme Court decision in Kleindienst v. Mandel 408 US 753 (1972), discussed in Nafziger, 32-34. The decision in Mandel has been taken at the Court of Appeals level to apply to all cases of visa refusals which engage the freedom of expression: e.g. American Academy of Religion v. Napolitano 573 F.3d 115 (2009), in which the refusal of a visa to Islamic scholar, Tariq Ramadan, was overturned on procedural grounds.

22 For example in Bustamante v. Mukasey 531 F.3d 1059 (2008).

238 USCA, 1229a(a)(1).

248 USCA $1225(\mathrm{~b})(1)$.

258 USCA 1187(b)(1).

${ }^{26}$ Within 'expedited removal', those who pass a 'credible fear' test in screening at a port of entry are admitted to the standard removal procedure involving an immigration judge, while those who fail this screening may have a hearing on the 'credible fear' question before a judge, which should occur within seven days: 8 USCA 1225(b)(1)(B). Those refused admission under the VWP, and who claim asylum - including those who present a false passport - are placed within an 'asylumonly' removal procedure before an immigration judge: 8 CFR 217.4(a)(1). 


\section{United Kingdom}

27 “Travel Passports from France”, Times, 28 February 1916.

28 See the parliamentary answer given by Home Secretary George Cave, House of Commons Debates, 19 March 1917, col. 1532.

${ }^{29}$ Home Office, "Immigration Appeals Bill: Aliens: Draft Instructions to Immigration Officers" Cmnd 3830 (November 1968), Appendix. In the case of Asia and Africa, the document listed only the non-Commonwealth countries exempt from visa requirements (five in each case). The figures given in the text are the author's estimates of the number of independent states in 1968 which were neither in the Commonwealth nor exempt.

${ }^{30}$ For the position as of 1 January 1983, see Statement of Changes in Immigration Rules, 1982-1983 House of Commons Papers 66, Appendix.

31 These were: Sri Lanka (1985), Bangladesh, Ghana, India, Pakistan (all 1986), Nigeria (1987), Haiti, Turkey (both 1989), Algeria, Morocco, Tunisia (all 1990), Uganda (1991), Ivory Coast, Sierra Leone (both 1994) and Gambia (1995).

32 From 4 April 1996, the UK was obliged to require visas of nationals of 101 states and other entities under EU Regulation $2317 / 95$ (1995 OJ L 234/1) and Regulation 574/ 1999 (1999 OJ L 72/2). The states which the UK added in 1996 were Tanzania (5 January 1996), Kenya (8 March 1996), then Bahrain, the Dominican Republic, Fiji, Guyana, Kuwait, the Maldives, Mauritius, Niger, Papua New Guinea, Peru, Qatar, Surinam, United Arab Emirates and Zambia (all 4 April 1996). After the UK ceased to be covered by the EU common visa policy (4 April 2001), the Maldives, Mauritius and Papua New Guinea were removed from its list (2002). 
of candidates was much reduced, only four states were definitively added between 1997 and 2003. ${ }^{33}$

From 1985 to 2003, when the United Kingdom acted unilaterally, its decision to introduce visa requirements for particular countries was often a means to forestall asylum applications. This was seen initially with Sri Lanka in 1985, when the Government was explicit that the measure was a response to an existing flow of Tamil asylum applicants. ${ }^{34}$ The introduction of visa requirements after a significant rise in asylum applications would later be seen in the cases of Turkey in 1989, Yugoslavia in 1992, Colombia in 1997, the Slovak Republic in 1998 and (among other factors) Zimbabwe in 2002. ${ }^{35}$ Avoidance of asylum applications was not always a central factor, however. For example, the justification given for the introduction in 1986 of visas for Bangladesh and India, and for visitors from Pakistan, was that this would enable arrivals from those countries to be managed, while giving security to travellers that they would be admitted upon arrival. ${ }^{36}$ In the cases of Algeria, Morocco and Tunisia in 1990, the then non-binding coordination of visa requirements among EU member states was given as the explanation. ${ }^{37}$ In 2003, the reason given for the introduction of a visa requirement for Jamaican nationals was that this would reduce overstaying. ${ }^{38}$

The most recent developments with respect to visa requirements began with the announcement in March 2007 of a systematic 'visa waiver test' for all states outside the European Economic Area (EEA). ${ }^{39}$ Among the detailed criteria to be

33 These were Colombia, Ecuador (both 1997), Zimbabwe (2002) and Jamaica (2003). The Slovak Republic was added in 1998 but removed in December 2003, some months before it joined the EU.

34 Home Secretary David Waddington, House of Commons Debates, 23 July 1985, cols 972-973.

35 Statement by Home Secretary Douglas Hurd, House of Commons Debates, 6 June 1989, written answers cols 45-46 (Turkey); statement by Home Secretary Kenneth Clarke, House of Commons Debates, 5 November 1992, cols 424-425 (former Yugoslavia); Home Office Minister, Mike O'Brien, quoted in "Crisis as Colombian refugees flood into Britain", Independent, 21 August 1997; Home Secretary Jack Straw, quoted in "Slovaks now required to have visa on entering UK", Guardian 8 October 1998; and Home Secretary David Blunkett, quoted in "Zimbabweans must get visas to enter UK”, Guardian, 8 November 2002.

36 Home Secretary Douglas Hurd, House of Commons Debates, 27 October 1986, cols 87-89.

37 Home Secretary David Waddington, House of Commons Debates, 23 February 1990, written answers, cols 958-959.

${ }^{38}$ Home Secretary David Blunkett, House of Commons Debates, 8 January 2003, written statements cols $10-11$.

39 Home Office, Securing the UK Border: Our vision and strategy for the future (March 2007), 9. The European Economic Area includes the $27 \mathrm{EU}$ member states, Iceland, Liechtenstein and Norway. Switzerland has a sui generis relationship with the EEA, which includes the free movement of persons. In line with the practice in United Kingdom immigration law, Switzerland is treated here as if it were an EEA member. 
applied, irregular migration risks featured prominently, defined as a "low incidence of identified immigration abuse, including denial of visas for entry to the UK owing to presentation of false documents, overstaying, illegal working and clandestine entry". Other criteria included the security of the state's passports; reporting of lost or stolen passports; co-operation in the repatriation and redocumentation of nationals; a low risk of terrorism and criminality; and, the economic impact of a visa requirement. This new approach was clearly influenced by the system in the United States, discussed above, not least in that the language of 'waiver' treats visa requirements as the norm, and exceptions as requiring of justification. The test eventually led to visa requirements being imposed on Bolivia, Lesotho, South Africa, Swaziland and Venezuela in 2009, and to the partial ending of the general visa requirement for Taiwan. ${ }^{40}$

At the time of writing, the result of the gradual expansion of UK visa requirements is that the nationals of 109 states and similar entities are covered, while 53 UN member states outside the EEA are visa-exempt. ${ }^{41}$ In addition, in recent years, the United Kingdom has expanded the range of migrants from visa-exempt states, who must obtain prior entry clearance. ${ }^{42}$ The current position is that a non-EEA national whose intended stay is for more than six months requires entry clearance in all cases. Even if the individual's stay is for less than six months, entry clearance is also required for many specific categories, including all of those coming to engage in economic activity. It is clear that the current British strategy is to expand entry clearance as far as possible. As a 2007 Home Office policy document on immigration control put it: "off-shoring our border control is the keystone of our border defence." ${ }^{3}$

The framework governing legal challenges to adverse immigration decisions is crucial to the strategy of maximising the reach of entry clearance. Firstly, those who are refused entry clearance may lack an effective legal remedy. While a refusal of entry clearance has in principle been covered by the immigration appeal system ever since the Immigration Act 1971, the reach of this entitlement has subsequently been narrowed. ${ }^{44}$ An Act of 1993 removed rights of appeal where (1)

${ }^{40}$ Home Secretary Jacqui Smyth, House of Commons Debates, 9 February 2009, column 51WS. Taiwanese nationals remain subject to a visa requirement if they possess a passport without an identification number.

${ }^{41}$ The list of states subject to a visa requirement is in the Immigration Rules, Appendix 1.

${ }^{42}$ Ibid, para 24 . There is an exception for persons with a subsidiary form of British nationality (who are subject to immigration control).

${ }^{43}$ Home Office, Securing the UK Border, 3.

${ }^{44}$ Immigration Act 1971, s 13(2). At the time of writing, the Asylum and Immigration Tribunal (AIT) has jurisdiction over entry clearance, under the Nationality Immigration and Asylum Act 2002, s 82(2)(b). The AIT also has jurisdiction with respect to refusals of family permits to the family members of EEA nationals: Immigration (European Economic Area) Regulations 2006, SI 2006 No 1003, Reg 26. 
the applicant was an intending visitor, short-term student, prospective student, 2 or dependants of these, or (2) the reason for the refusal of entry clearance was that the individual did not possess a 'relevant document' (e.g. passport, identity document or work permit), or did not meet specified requirements as to age, nationality or period of intended stay. ${ }^{45}$ The effect of those changes was only partly offset by legislation in 1999 which restored a right of appeal for family visitors. ${ }^{46}$ A second curtailment of appeal rights came in 2008 , with the removal of appeals concerning the points-based system - that is, by economic migrants, students and their dependants. ${ }^{47}$ As Clayton points out in her chapter in this collection, the result is that overseas appeal rights are effectively limited to family cases.

A second legal point is that only those who reach the United Kingdom whether because they are not subject to entry clearance requirements, or because they reach the UK in spite of them - have the possibility to claim international protection, under the Geneva Convention and/or the ECHR. An equivalent possibility is not open to those refused entry clearance. Within United Kingdom legislation, this result is achieved by section 95 of the Nationality Immigration and Asylum Act 2002, which does not allow an appeal based on a claim for international protection by a person who is outside the territory. ${ }^{48}$

Thirdly, there are doubts as to the extent to which fundamental rights arguments may be made to challenge United Kingdom entry clearance refusals. Following the incorporation of the ECHR into United Kingdom law by the Human Rights Act 1998, the Immigration and Asylum Act 1999 introduced a general right to appeal all negative immigration decisions on ECHR grounds. However, in its decision in Moon in 2005, the Asylum and Immigration Tribunal held that the ECHR does not cover entry clearance refusals, other than those concerning the guarantee of family life in its Article $8 .^{49}$ This outcome may be contrasted not just with that in the United States, but also with the German and Belgian case law concerning the Unification Church discussed in Evelien Brouwer's contribution to this collection.

45 Immigration Act 1971, s 13, as amended by Asylum and Immigration Appeals Act 1993, ss 10 and 11 .

46 Immigration and Asylum Act 1999, ss 59, 60 and 65.

47 Amendment of ss 88A, 90 and 91 of the 2002 Act by the Immigration Asylum and Nationality Act 2006, s 4, read together with the Immigration, Asylum and Nationality Act 2006 (Commencement No. 8 and Transitional and Saving Provisions) Order 2008, SI 2008 No. 310 .

48 There is an exception for those who are removed from the UK while an appeal is pending.

49 Moon USA [2005] UKIAT 00012, discussed in more detail in Clayton's chapter in this volume. 
It remains possible for those lacking appeal rights to bring judicial review claims to the High Court. Judicial review action taken by immigration applicants outside the territory should not be thought impossible. This is illustrated by the Farrakhan decision in 2002, where the applicant unsuccessfully challenged an exclusion order, and by the Yousaf decision in 2009, in which the applicant unsuccessfully challenged the non-issue of a work permission. ${ }^{50}$ Nevertheless, potential applicants are likely to be deterred in most cases by the potential costs of unsuccessful judicial review proceedings, and will generally prefer to make a fresh visa application.

\section{European Union}

European Union policy on short-stay visas (up to three months) concerns the 28

${ }^{50} R$ (Farrakhan) v Secretary of State for the Home Department [2002] QB 1391 and $R$ (Yousaf) v. Secretary of State for the Home Department [2009] EWHC 1006.

${ }^{51}$ Visas for stays of over 3 months are governed by the law of the member states: Article 18 of the Schengen Implementing Convention 1990, as substituted by Regulation 1091/ 2001 (2001 OJ L 150/4).

52 Regulation 539/2001 (2001 OJ L 81/1), as amended.

${ }^{53}$ For a discussion of the negotiation of Regulation 2317/ 95 (above), see Steve Peers, "The Visa Regulation: Free movement blocked indefinitely” European Law Review 21 (1996): 150-155.

54 Presidency Conclusions to the Seville European Council, 21 and 22 June 2002 (available from http://europa.eu/european-council/index_en.htm), para 30.

55 COM (2002) 679, 3 December 2002, p 2. Ecuador's status was changed by Regulation 543/ 2003 (2003 OJ L 69/10).

56 COM (2006) 84, 13 July 2002, p 2. Bolivia's status was changed by Regulation 1932/2006 (OJ 2006 L 405/ 23). 
states are likely to be moved to the positive list when there is thought to be a low 2 risk of irregular migration, and reciprocity in visa-free travel can be agreed with them. In particular, that was the reason for the transfer of six Commonwealth states from the negative to the positive lists during 2009, after the signature of agreements on reciprocity in visa waivers between them and the EU. ${ }^{57}$

An important difference between the EU system and those of the United States and United Kingdom is that rights of appeal against visa refusals are recognised. In relation to long-term visas (over three months), a right of legal challenge is provided for in Directives on the admission of family members, students, researchers and highly qualified employees. ${ }^{58}$ More recently, the Visas Code, adopted in July 2009, provides that those refused short-term visas (up to three months) shall have an entitlement both to know the reasons, and to an appeal "conducted in accordance with ... national law." 59 These provisions are stronger than the previous position, under the Common Consular Instructions, which left participating states with competence over both reasons and appeals. ${ }^{60}$ The greater provision for avenues of legal challenge within the EU suggests that legal considerations play less of a role within its visa policy. Legal factors are still significant, however, given that visa refusals frustrate the possibility to apply for asylum, and that rights of legal challenge are likely to be harder to exercise from abroad. With respect to the latter, it is revealing that, in the drafting of the Visas Code, the Council of Ministers removed a clause from the Commission proposal which would have required a notice of refusal of a visa to include information concerning legal representation. ${ }^{61}$ This outcome may be contrasted with the

57 Council Decisions of 6 April 2009 concerning Antigua and Barbuda, Bahamas, Barbados, Mauritius, Saint Kitts and Nevis and Seychelles, published in OJ 2009 L 169/1. The possibility to change their status had been created by an amendment to the 2001 Regulation in 2006: see Regulation 1932/2006 (above).

58 Directive 2003/ 86 on family reunion (OJ 2003 L 251/12), Article 18; Directive 2004/ 14 on the admission of students (OJ 2004 L 375/12), Article 18(4); Directive 2005/ 72 on the admission of researchers (OJ 2005 L 289/ 15), Article 15(4); Directive 2009/50 on entry and residence for highly qualified employment (OJ 2009 L 155/17), Article 11(3). None of these applies to Denmark or the United Kingdom, while only the directive on researchers applies to Ireland. These are not Schengen measures, and therefore do not apply to non-EU states.

59 Regulation 810/2009 establishing a Community Code on Visas (2009 OJ L 243/1), Article 32(3). The Visas Code is part of the Schengen system, and so applies to Iceland, Norway and Switzerland, while Denmark has a choice as to whether it participates. It does not apply to Ireland or the United Kingdom. For a commentary on the Code, see Annalisa Meloni, "The Community Code on Visas: Harmonisation at Last?” European Law Review 34 (2009): 671-695.

${ }^{60}$ Common Consular Instructions on Visas for Diplomatic Missions and Consular Posts, OJ 2005 C 326/1, para 2.4 .

${ }^{61}$ Article 23(3) of the Commission proposal, COM (2006) 403. 
requirement to provide that information in the equivalent provision of the Schengen Borders Code, for those refused entry at the external borders of the Schengen zone. ${ }^{62}$

\section{Pre-embarkation controls}

A second way for a state to 'extraterritorialise' its immigration policy is for it to send its immigration or border officials outwards, in order to encounter travellers

\footnotetext{
${ }^{62}$ Regulation 562/2006 establishing a Community Code on the rules governing the movement of persons across borders, OJ 2006 L 105, Article 13(3).

${ }_{63}$ The information in this paragraph is taken from Government of Canada, Preclearance Act Review: Information Document (February 2009).

${ }^{64}$ Agreement signed on 8 May 1974, 953 UNTS 255.

${ }^{65}$ Agreement signed on 18 January 2001, available at http://www.treaty-accord.gc.ca/text-texte .asp?id=103842 (accessed 3 November 2009).

${ }^{66}$ Calgary, Edmonton, Halifax, Montreal, Ottawa, Toronto, Vancouver and Winnipeg.
} 
The United States has also entered international agreements with respect to 2 Bermuda, the Bahamas (both in 1974) and Aruba (1987 and 1994), which permit both immigration checks and controls on goods. ${ }^{67}$ As with Canada, the main purpose of these agreements appears to be to facilitate travel, by permitting flights to all destinations in the United States. In the case of Bermuda, a further agreement in 2009 will, when implemented, extend pre-clearance to private aircraft. ${ }^{68}$

In addition, the United States conducts immigration controls at airports in Ireland. This system, known as 'pre-inspection', began in Shannon in 1986 (initially as a pilot) and was extended to Dublin in 1994 when direct flights commenced from there to the United States. ${ }^{69}$ Because pre-inspection at the Irish airports has hitherto involved immigration controls alone, it has not so far been implied the possibility of landing at domestic United States airports or terminals. This will presumably change with the implementation of a second agreement, concluded between the United States and Ireland in November 2008, which provides for full pre-clearance, including inspections of goods, and for the application of controls to private aircraft. ${ }^{70}$ In the absence of flights to domestic airports and terminals, the main purpose of these arrangements has probably been to allow the United States to refuse admission to travellers from Ireland. A further factor, which has been relied upon by the Irish government in order to justify these arrangements, is that United States immigration controls encourage reliance upon Shannon by transatlantic traffic. ${ }^{71}$ It is unlikely to be coincidental that the United States has a strategic interest in Shannon's commercial viability, as it uses the airport for stopovers by military aircraft.

While the United States preclearance arrangements - the Irish case apart have mainly been adopted for reasons of traveller convenience, there is an immigration law dimension as well. Under US immigration law, a decision taken

${ }^{67}$ In relation to Bermuda, Agreement between the United Kingdom and United States signed on 15 January 1974 (928 UNTS No 95); Agreement between the United States and Bahamas signed on 23 April 1974 (953 UNTS No 201); in relation to Aruba, Agreements between the Netherlands and the United States signed on 16 June 1987 (1520 UNTS 27) and on 2 December 1994 (1948 UNTS 77).

${ }^{68}$ Department of Homeland Security, "Secretary Napolitano Signs Agreement on Aviation Preclearance Security Operations with Bermuda," press release, 23 April 2009.

69 Agreement signed on 25 June 1986, 1438 UNTS 11.

70 Department of Homeland Security, "DHS Reaches Agreement with Ireland on Aviation Preclearance," press release 17 November 2008. The text of the agreement can be found as an Annex to Ireland's Aviation (Preclearance) Act 2009.

71 Minister for Communications, Jim Mitchell on the 1986 agreement, Dáil Debates, 6 June 1986, cols 1444-1453 and Minister for Transport, Noel Dempsey, Dáil Debates, 30 June 2009, cols $290-293$. 
within preinspection has "the same effect ... as though made at the destined

728 CFR 235.5.

73 An earlier account, on which this summary draws, is in Bernard Ryan, "The European Dimension to British Border Control” Immigration Asylum and Nationality Law 18 (2004): 8-18.

${ }^{74}$ The legal basis is in the Sangatte Protocol to the 1986 Treaty of Canterbury between France and the United Kingdom (the governing agreement for the channel tunnel), published as Cm 2366 (1993).

75 This is the 'Additional Protocol', published as Cm 5015 (2000).

76 The agreed provisions concerning the Belgium-United Kingdom route can be found in Schedule 2 to the Channel Tunnel (Miscellaneous Provisions) Order 1994 (SI 1994 No. 1405), as amended by the Channel Tunnel (Miscellaneous Provisions) (Amendment) Order 2004 (SI 2004 No. 2589). These derive from an initial agreement in 1993, and an administrative arrangement in 2004.

77 This is the 'Le Touquet Treaty', published as Cm 5832 (2003). 
tunnel controls: once security checks are made on vehicles prior to entry into the 2 tunnel, it reduces delay if immigration and other frontier controls also take place at that stage. While subsequent developments at Eurostar stations and ferry ports can be rationalised in similar terms, in fact these were mainly introduced in order to frustrate irregular migration to the United Kingdom, and the making of asylum claims there. The background to the Eurostar juxtaposed controls was the increase in undocumented arrivals and persons claiming asylum at the terminus in London (then Waterloo). ${ }^{78}$ Equally, the extension of immigration controls to the ferry ports was intended to address irregular migration pressures around Calais, and was decided upon by the two governments in 2002 at the same time as the French government agreed to close the Red Cross humanitarian camp for migrants at nearby Sangatte. ${ }^{79}$

This immigration control objective has been furthered by three aspects of the international arrangements. Firstly, the agreements concerning the channel tunnel and ferry ports include provision for a 'control zone' within which officials the state of destination are allowed to operate. ${ }^{80}$ The United Kingdom border authorities use their 'control zones' in order to conduct X-ray, carbon dioxide and other checks, in order to detect migrants concealing themselves on trucks bound for the United Kingdom. Secondly, the agreements between France and the United Kingdom concerning the Eurostar and ferry ports provide that asylum claims are the responsibility of the state of departure, until the closure of the train doors or the departure of the vessel. ${ }^{81}$ Thirdly, all of the arrangements referred to provide that a person refused access to the destination territory is the responsibility of the state of departure. ${ }^{82}$

The limited avenues for legal challenges are again central to understanding the success of juxtaposed controls. United Kingdom law was modified in 2000 to make clear that immigration officers who are outside the territory may examine passengers, including by giving or refusing leave to enter, and may cancel leave to enter deriving from entry clearance. ${ }^{83}$ It is not clear however that the same extension applies to rights of appeal. Claims of international protection are undoubtedly

${ }^{78}$ Home Office Minister Lord Bassam, House of Lords Debates 16 March 2001, cols 1124-1125

79 For both announcements, see 'Closure Timetable set for Sangatte Centre,' Immigration and Nationality Directorate press release, 12 July 2002.

${ }^{80}$ Article 5 of the Sangatte Protocol and Article 3 of the Le Touquet Treaty.

${ }^{81}$ Article 4 of the Additional Protocol and Article 9 of the Le Touquet Treaty. There is no equivalent statement in the published agreements with Belgium, but it is to be presumed that a similar practice applies.

82 Article 18 of the Sangatte Protocol, Article 3 of the Additional Protocol, Article 6 of the 2004 agreement with Belgium and Article 7 of the Le Touquet Treaty.

${ }^{83}$ Immigration (Leave to Enter or Remain) Order 2001 (SI 2001 No 1161), Article 7. 
blocked by section 95 of the Nationality Immigration and Asylum Act 2002 Act (referred to in the previous section), which precludes appeals on this ground by persons outside the United Kingdom. In other cases, the approach of the immigration authorities appears to be to allow appeals on the same basis as if the individual had been refused entry at a United Kingdom port. ${ }^{84}$ A potential problem for that approach is the legislative provision whereby refusal of leave to enter gives rise to a right of appeal only if, "on ... arrival in the United Kingdom," the individual had entry clearance. ${ }^{85}$ It is arguable on logical grounds that the reference to "arrival in the United Kingdom" excludes a right of appeal in all cases where leave to enter is refused - including by the cancellation of leave ${ }^{86}$ - before the individual has reached the United Kingdom. If that was the intention behind this phrase, however, this was not communicated to Parliament when the phrase was inserted into the legislation as part of the amendment of rights of appeal in 2006. Then, the Government focused on the removal of rights of appeal from all those without entry clearance (the point discussed in the previous section), and did not refer a further exclusion of rights of appeal for persons with entry clearance, but prevented from embarking at a juxtaposed control. ${ }^{87}$

It may be added that any general exclusion of rights of appeal is inapplicable to EEA nationals and their family members, as a refusal to admit them at a juxtaposed control is presumably an example of an "EEA decision" which they may challenge. ${ }^{88}$ For non-EEA cases, it also remains possible to claim either race discrimination or a breach of the ECHR. ${ }^{89}$ As we have seen, however, there are doubts in the United Kingdom as to the extraterritorial applicability of the ECHR in non-family cases.

A final point concerns the position where persons are refused entry to France at the reciprocal juxtaposed controls operating at departure points in the United Kingdom. This is governed by the Schengen Borders Code, which sets out the general principle that a person who is refused entry at a Schengen border is entitled both to "a substantiated decision stating the precise reasons for the refusal"

\footnotetext{
${ }^{84}$ See UK Border Agency, Border Force Operations Manual: Appeals, http://www.ukba.homeoffice .gov.uk/policyandlaw/guidance/borderforceoperationsmanual/ (accessed 3 November 2009).

${ }^{85}$ Nationality Immigration and Asylum Act 2002, section 89(1).

${ }^{86}$ Note that cancellation of continuing leave is treated as if it were a refusal of leave to enter, under Immigration Act 1971, Sch 2, para 2A(9).

${ }^{87}$ See the remarks of Baroness Ashton, House of Lords Debates, 11 January 2006, cols GC94-GC95.

${ }^{88}$ The category of "EEA decision" includes "a decision ... that concerns a person's... entitlement to be admitted to the United Kingdom": Immigration (European Economic Area) Regulations 2006 (SI 2006 No 1003), Reg 2(1), while the right of appeal against EEA decisions (ibid, Reg 26) does not have an express territorial limit.

89 Nationality Immigration and Asylum Act 2002, section 89(2).
} 
and to an appeal "in accordance with national law." ${ }^{0}$ The Code includes specific 2 provisions permitting pre-departure checks upon travellers on high-speed trains and ships, based on international agreements between the states concerned. ${ }^{91}$ It may be inferred from these references within the Code that the general principle of a right of appeal also applies to immigration refusals taken prior to departure.

\section{Co-operation with carriers}

Legal obligations upon the carriers of passengers who are not admitted to a state

have a long history. In the nineteenth century, US states and cities with seaports often obliged carriers to post bonds for migrants considered likely to become a 10 public charge. ${ }^{92}$ Perhaps the first example of a carriers' obligation linked to systematic immigration control was Australia's Immigration Restriction Act 1901. Reflecting the 'white Australia' policy of the newly formed state, the 1901 Act 12 imposed a penalty on carriers who brought non-European passengers to Australia 13 who were not admitted - usually, because they failed a literacy test designed to 14 exclude them. ${ }^{93} \mathrm{~A}$ further development was the linking of carriers' obligations to the lack of a visa, which appears to have first been done by the United States' Passenger Act 1924. ${ }^{94}$

Carriers' penalties for bringing inadequately documented passengers are now common. For example, Australia's Migration Act includes an offence to bring a non-citizen to the country without a visa. ${ }^{95}$ The United States imposes penalties on carriers who bring foreigners without a valid passport and (if required) a valid visa. ${ }^{96}$ European states began to adopt carriers' sanctions from the mid-1980s onwards, with Germany, the United Kingdom doing so in 1987, France and Italy in 1993 and the Netherlands in $1994 .{ }^{97}$ In the same period, carriers'

90 Regulation 562/2006, Article 13.

91 Ibid, Annex VI, paras 1.2.2 and 3.1.1. Note that a refusal of entry at the channel tunnel is argu- 27 ably not covered by the concept of a 'high speed train'.

92 For a detailed account of selective bonds, see Benjamin Klebaner, "State and Local Immigration 29 Regulation in the United States before 1882" International Review of Social History 3 (1958): 30 274. For a discussion of their place in the history of US immigration control, see Aristide 31 Zolberg, "The Archaeology of 'Remote Control', in Migration Control in the North Atlantic 32 World, ed. Andreas Fahrmeir, Olivier Faron and Patrick Weil (New York, Berghahn: 2003). 33

93 Immigration Restriction Act 1901, section 9. For the history of the 1901 Act, see A.T. Yarwood, 34 Asian Migration to Australia: The Background to Exclusion 1896-1923 (Melbourne: Melbourne 35 University Press, 1964) 19-41.

94 Immigration Act 1924, section $16 . \quad 37$

${ }_{95}$ Migration Act 1958, section 229.

968 USCA 1323.

97 For a detailed account, see Antonio Cruz, Shifting Responsibility: Carriers' Liability in the Member 40 States of the European Union and North America (Stoke-on-Trent, Trentham Books: 1995), 27-66. 41 
sanctions also came to be required at the international level. In particular, the 1990 UN Migrant Smuggling Protocol - to which there are 150 parties at the time of writing - requires states to oblige "commercial carriers ... to ascertain that all passengers are in possession of the travel documents required for entry into the receiving State." ${ }^{98}$ In addition, since 1997, Schengen rules have obliged participating states to impose penalties upon the carriers of inadequately documented non-EU nationals. ${ }^{99}$

Other contemporary legal provisions require carriers to bear the costs of the detention and/ or removal of passengers who are not admitted under immigration laws. For example, in the United Kingdom, the Immigration Act 1971 permits an immigration officer to direct a carrier to remove a person they have brought to a port and who has been refused entry. ${ }^{100}$ Similarly, the Schengen rules on carriers oblige member states to require carriers to return inadequately documented passengers.

For our purposes, the significance of carriers' penalties and other obligations is that they provide an incentive for carriers to co-operate with immigration officials. One form of co-operation is known as 'carrier liaison', and involves the stationing of immigration officials at embarkation points in order to give advice to carriers, particularly in relation to the adequacy and genuineness of passenger documents. Carriers' liaison schemes were generally set up in the decade after the mid-1980s, as visa requirements and carriers' sanctions expanded. For example, Australia and Canada began liaison operations in 1989, New Zealand did so in 1991, the United Kingdom in 1993 and the Netherlands in $1994 .{ }^{101}$ In the case of the United States, a limited 'carrier consultant program' was in place in 1994, aimed at training airline staff and government overseas government officials in the review of passenger documents. ${ }^{102}$ The most recent version of carrier liaison in the United States is the

The United Kingdom provision for carriers' penalties is now in the Immigration and Asylum Act 1999, section 40, which refers both to identity documents and visas (where required).

98 Migrant Smuggling Protocol, Article 11(3) and (4).

99 Schengen Implementing Convention (above), Article 26 and Directive 2001/ 51 (OJ $2001 \mathrm{~L}$ 187/45). The United Kingdom has elected to participate in these Schengen measures.

100 Immigration Act 1971, Schedule 2, para 8.

101 For the first four states, information is in Government Accountability Office, Aviation Security: Efforts to Strengthen International Passenger Prescreening are Under Way, but Planning and Implementation Issues Remain, Report GAO-07-346, May 2007, Table 1. For the Netherlands, see Sophie Scholten and Paul Minderhoud, "Regulating Immigration Control: Carrier Sanctions in the Netherlands" European Journal of Migration and Law 10 (2008): 123, 137.

102 See the evidence of Immigration and Naturalization Service Commissioner Doris Meissner to the Senate Commission on the Judiciary, hearing on Proposals for Immigration Reform, 15 June 1994, referring to the posting of officials to Pakistan and the Netherlands. 
'immigration advisory program', which aims to prevent the travel of those with inadequate documents or who pose a security threat. ${ }^{103}$

A second form of co-operation between carriers and immigration authorities is preferential schemes, through which carriers' either avoid liability or benefit from reduced sanctions, if they comply with specified procedures. For example, Britain has had an 'approved gate check' system since 1992, in order to protect carriers against passengers disposing of their documents after embarkation. ${ }^{104}$ Canada has a system whereby a 'memorandum of understanding' between an airline and the Canadian Border Services Agency can lead to a full or partial reduction in the amount of an administrative fine for persons not admitted. ${ }^{105} \mathrm{In}$ the case of the Netherlands, the introduction of carriers' sanctions led to a 'memorandum of understanding' between the immigration authorities and KLM, the main international carrier, which came into force in April 2000. Under that agreement, in return for the KLM agreeing to implement checks on every passenger, to train its staff, and to follow immigration officials' advice in all cases, it was agreed that it would not be prosecuted for inadequately documented passengers, up to a defined annual quota. ${ }^{106}$

Part of the significance of carrier liaison operations is that they lead to the involvement of immigration officials in refusing permission to travel to individual passengers. Many examples may be given to illustrate the general point. Canadian officers participated in the interception of 10,984 inadequately documented passengers in the decade from 1991-2000. ${ }^{107}$ In the case of the United Kingdom, official figures show that 180,000 passengers were refused boarding because of the work of airline liaison officers between 2001 and $2007 .{ }^{108}$ The Netherlands' immigration authorities advised carriers not to allow boarding in

${ }^{103}$ Information from General Accountability Office, Visa Waiver Program: Actions Are Needed to Improve Management of the Expansion Process, and to Assess and Mitigate Program Risks (GAO08-1142T, 24 September 2008), 11.

${ }^{104}$ For an early discussion, see Frances Nicholson, "Implementation of the Immigration (Carriers' Liability) Act 1987: Privatising Immigration Functions at the Expense of International Obligations?" International and Comparative Law Quarterly 46 (1997): 586, 592-593. Current information can be found at http://www.ukba.homeoffice.gov.uk/aboutus/workingwithus/ transportindustry/ (accessed 3 November 2009).

105 Immigration and Refugee Protection Regulations 2002 (SOR 2002 No 227), Reg 20 and Citizenship and Immigration Canada, Obligations of Transporters (Manual ENF 15, 13 February 2009), para 9.2.

106 Scholten and Minderhoud, 140-143.

107 Citizenship and Immigration Canada, Review of the Immigration Control Officer Network: Final Report (2001), section 3.0.

108 Immigration Minister Liam Byrne, House of Commons Debates, 22 July 2008, Column 1353W. 
3,500 cases in $2004 .{ }^{109}$ In the case of the United States, a pilot programme in Madrid led to 435 passengers being prevented from travel between February 2008 and June 2009. ${ }^{110}$

The expansion of carriers' obligations from the mid-1980s, and the related development of co-operation between carriers and immigration authorities, have often been designed to uphold visa requirements, and therefore to prevent irregular migration and to frustrate potential asylum applications. ${ }^{111}$ From a legal perspective, the consequence of these developments is that the effective decision to prevent travel is no longer taken by immigration officials, but rather by the carriers themselves. The consequence of this 'privatisation' is to further distance states from the prospect of legal action based on an individual's entitlement to travel and from claims to international protection. There is little or no prospect of a successful legal action against the carrier either, as is illustrated by unsuccessful litigation in the United Kingdom concerning alleged breach of EU free movement of persons principles and race discrimination. ${ }^{112}$ Equally, it may be thought relatively unlikely that carriers will allow someone to travel who is inadequately documented, in order that they may make an asylum claim upon arrival, notwithstanding that carriers' penalty regimes often contain an exception for passengers who succeed in such claims. ${ }^{113}$

\section{Interdiction at sea}

A third form of extraterritorial immigration control is the interdiction of vessels at sea - that is, action taken by states to prevent sea-borne migrants from reaching their intended destination. This kind of enforcement activity differs from that discussed in previous sections, in that it is concerned with migration by irregular channels, rather than with passengers seeking to travel by 'regular' routes. As a consequence, the primary role of officials from the state of destination is not to take a decision on whether the individual should be admitted to the state's territory. Rather, the destination state's primary objective is to prevent migrants from reaching the state's territory by irregular means.

\footnotetext{
109 Scholten and Minderhoud, 138.

110 Department of Homeland Security, "United States and Spain Formalize Arrangement to Interdict High-Risk Travelers", press release, 1 July 2009.

111 For a discussion of the latter dimension, see Erika Feller, "Carrier Sanctions and International Law” International Journal of Refugee Law 1 (1989): 48.

112 Naraine v. Hoverspeed [2000] EuLR 321 (Court of Appeal).

113 In the case of the United Kingdom, see UK Border Agency, Borders Force Operations Manual: Carriers' Liability, section 9, available at http://www.ukba.homeoffice.gov.uk/policyandlaw/ guidance/borderforceoperationsmanual/ (accessed 3 November 2009).
} 
Probably the first case of systematic enforcement action at sea against irregular 2 migration was that taken by Britain against unauthorised Jewish arrivals to Palestine in the late 1930s and between 1945 and 1948. ${ }^{114}$ These British measures included the deployment of its navy, first between July and September 1939, and then from October 1945. ${ }^{115}$ The main objective of these controls was not interdiction, but interception - that is, the identification of vessels, with a view to the arrest of vessels and their passengers once they entered territorial waters. The practical result of these interceptions for most passengers was deportation, principally to Cyprus in the postwar phase. Operations in international waters were constrained by Britain's position as a leading maritime power, which led it to defend the freedom of the high seas. For example, in 1946, the British government rejected a proposal from its admiralty to permit searches and arrests in international waters where vessels lacked an identifiable master or a recognised flag. The official policy remained that police action in international waters required either a state of war or treaty authorisation by the flag state. ${ }^{116}$

A second leading case of immigration enforcement at sea concerned the Vietnamese 'boat people' who attempted to reach neighbouring countries at various periods between 1975 and $1992 .{ }^{117}$ In this case, forms of interdiction were practiced by destination states, through refusals to allow vessels to land, and through 'push backs' of boats to international waters. Singapore adopted an especially restrictive policy towards boat arrivals from Vietnam, and refused to allow migrants' vessels to land as early as May $1975 .{ }^{118}$ Malaysia and Thailand also engaged in policies of taking boats out to international waters, particularly in 1978-1979 and 1988-1989. ${ }^{119}$ These latter measures were among the main reasons for the conclusion of international arrangements for the Vietnamese in 1979

114 On the history of the period, see Jacob Hurewitz, The Struggle for Palestine (New York, Norton: 1950). The immigration control measures in the postwar phase are discussed in Arieh Kochavi, Post-Holocaust Politics: Britain, the United States and Jewish Refugees, 1945-1948 (Chapel Hill, University of North Carolina Press, 2001).

115 Ninian Stewart, The Royal Navy and the Palestine Patrol (London, Frank Cass: 2002) for an official navy account of these operations. For the postwar period see Fritz Liebreich, Britain's Naval and Political Reaction to the Illegal Immigration of Jews to Palestine, 1945-1948 (London, Routledge: 2005) 91-92, particularly in relation to archive material.

116 Stewart, 89-92 and Liebreich, 122-126. In practice, the rules were relaxed informally, so as to allow the arrest of vessels near territorial waters (up to 16 nautical miles).

117 See generally, Bruce Grant, The Boat People: An Age' Investigation (Harmondsworth, Penguin: 1979) and W.C. Robinson, Terms of Refuge: The Indochinese Exodus and the International Response (London, Zed Books: 1998).

118 General Accounting Office, The Indochinese Exodus: A Humanitarian Dilemma (24 April 1979), 9.

119 Robinson, 42-43, 181-183, 190. 
and 1989, based on processing in the region, and resettlement in western coun-

\section{tries for those accepted as refugees.}

The responses to Jewish migration to Palestine and to the Vietnamese boat people had in common that the destination states were not taken to be covered by obligations of non-refoulement. The remainder of this section will consider more recent cases of interdiction strategies where the avoidance or minimisation of responsibility under international refugee law has been part of states' motivations: US interdiction policies since 1981, Australia's interdiction policies between 2001 and 2007, and ongoing enforcement action led by Italy and Spain aimed at migration from Africa.

\section{United States interdiction}

United States interdiction policies - discussed in detail in Niels Frenzen's contribution to this volume - have been in effect since 1981, and have mainly concerned persons making irregular journeys from Caribbean countries. These began as a belated reaction to the 'Mariel boatlift' from Cuba in the summer of 1980, when an estimated 124,776 persons reached the Florida coast. ${ }^{120}$ The Mariel boatlift was followed by a decision to curtail immigration by Haitians, with respect to whom there were not the same political reasons to allow admission. In September 1981, after an agreement with Haiti, which allowed the United States to interdict vessels departing from its territory, President Reagan issued a executive order authorising interdiction in order to prevent "the entry of undocumented aliens from the high seas". ${ }^{121}$ In October, the Coast Guard began patrolling the Windward Passage, to the west of Haiti and to the east of Cuba. ${ }^{122}$

Interdiction operations have continued against irregular migration by Haitians since 1981. Interdiction has also been practiced in the Straits of Florida since an attempted re-run of the Mariel boatlift in August 1994. ${ }^{123}$ A third strand is the interdiction of those seeking to travel through the Mona Passage from the Dominican Republic to Puerto Rico, which began in April 1995. ${ }^{24}$ US Coast Guard figures show that, over the period from 1982 to September 2009, a total of

\footnotetext{
${ }^{120}$ Kathleen Newland, "The US and the Caribbean," in Joanne van Selm and Betsy Cooper, The New "Boat People": Ensuring Safety and Determining Status (Washington DC, Migration Policy Institute: 2006) 72.

${ }^{121}$ Agreement of 23 September 1981, 33 UST 3559, TIAS 10241; Executive Order 12324, 46 Federal Register 48109 (29 September 1981).

122 "Vessel Begins Vigil for Aliens Today", New York Times, 10 October 1981.

${ }^{123}$ Newland, 73-74.

124 US Coast Guard, "Alien Migrant Interdiction": http://www.uscg.mil/hq/cg5/cg531/amio.asp (accessed 3 November 2009).
} 
114,718 Haitians, 66,702 Cubans and 35,756 Dominicans were interdicted as a result of its operations. ${ }^{125}$ The Coast Guard has also engaged in immigration control on vessels travelling from China, particularly to Guam, and interdicted 5,912 Chinese nationals over the same period. ${ }^{126}$ In addition, since 1999, a total of 8,257 Ecuadorian nationals have been interdicted on immigration grounds, presumably primarily in the Pacific. ${ }^{127}$

One legal question posed by United States interdiction on the high seas is whether it has a basis in international law. The 1981 executive order, and its successor in February 1992, expressly limited interdiction to vessels without nationality, or with whose flag state there were "arrangements" authorising interdiction. ${ }^{128}$ In the case of Haiti, the agreement of September 1981 allowed the detention and return of Haitian flag vessels and their passengers, where the US authorities determined after a preliminary visit that "an offense against United States immigration laws ... has been or is being committed." That international agreement was however terminated by the Aristide government in 1994, after the US suspended its bar on the return of refugees between 1992 and 1994. ${ }^{129}$ In the case of Cuba, permission for interdiction arguably comes from a joint statement between the two governments in May 1995 on the "normalization of migration". This text provided that "effective immediately, Cuban migrants intercepted at sea by the United States and attempting to enter the United States will be taken to Cuba." ${ }^{130}$ In the case of the Dominican Republic, a May 2003 agreement gives general permission to United States vessels to board Dominican vessels on the high seas which are suspected of engaging in migrant smuggling, and to return those on board to the Dominican Republic. ${ }^{131}$ For countries other than Cuba and the Dominican Republic, if there is a current legal basis for interdiction, it must either lie in individual authorisations, or derive from lawful

125 US Coast Guard, "Alien Migrant Interdiction: Total Interdictions - Fiscal Year 1982 to Present": http://www.uscg.mil/hq/cg5/cg531/AMIO/FlowStats/FY.asp (accessed 3 November 2009). 29

126 Ibid. Not all of these interdictions of Chinese nationals may have taken place on vessels travelling directly from China.

127 Ibid. Only two Ecuadorians had been interdicted before 1999.

128 Executive Order 12324, section 2; Executive Order 12807, 57 Federal Register 23133 (1 June 1992), section 2.

129 See Executive Order 12807 (57 Federal Register 23133, 14 May 1992), discussed in Stephen Legomsky, "The USA and the Caribbean Interdiction Program" International Journal of Refuge Law 18 (2006): 677, 681-682 and "Aristide Renounces Treaty Allowing US To Return Haitians", Interpreter Releases, 11 April 1994, 481.

130 "Joint Statement With the Republic of Cuba on Normalization of Migration", 2 May 1995, 31 Weekly Compilation of Presidential Documents 752.

131 Agreement concerning cooperation in maritime migration law enforcement, 20 May 2003, available on Lexis (2003 UST Lexis 32), Articles 8 and 10. 
boarding under agreements concerning traffic in illicit drugs, such as that with Haiti. ${ }^{132}$

Specific provision for refugees has to date been made in two international agreements permitting the interdiction of migrants. The September 1981 agreement with Haiti included the statement that "under these arrangements the United States Government does not intend to return to Haiti any Haitian migrants whom the United States authorities determine to qualify for refugee status.” Similarly, the 2003 agreement with the Dominican Republic provides that there should not be involuntary return of a person who has "a well-founded fear of persecution" on Geneva Convention grounds, or "there are substantial grounds for believing that the person would be in danger of being subjected to torture."133

In addition, irrespective of specific international agreements, US practice has generally been to allow those interdicted in the Caribbean to make known their desire for protection. It appears that those interdicted on their way from Cuba or China have been informed of this possibility automatically, whereas those arriving from elsewhere have been required to spontaneously indicate a desire for protection when taken on board Coast Guard vessels (the 'shout test'). ${ }^{134}$ Since 1994 , individuals who indicate a protection need have generally been transferred to immigration detention at Guantánamo Bay for an assessment of their case. ${ }^{135}$ If successful, they have been resettled somewhere other than the United States. ${ }^{136}$ In practice, however, success rates have been very low. For example, between May 1995 and July 2003, only 170 Cuban refugees were resettled from Guantánamo Bay. ${ }^{137}$ Equally, between February and July 2004 - at a time when an armed rebellion in Haiti had forced its president to leave the country - of 2830 Haitians interdicted, only 35 cases were examined, and only six persons were recognised as refugees. ${ }^{138}$

${ }^{132}$ Agreement between the United States of America and the Republic of Haiti concerning Cooperation to Suppress Illicit Maritime Drug Traffic, signed on 6 May 1997 (available on Westlaw, 2002 WL 31504914).

${ }_{133}$ Agreement of 20 May 2003, Article 10.

${ }^{134}$ Joanne van Selm and Betsy Cooper, The New "Boat People": Ensuring Safety and Determining Status (Washington DC, Migration Policy Institute: 2006), 11-12.

${ }_{135}$ Legomsky, 682-684.

136 Ibid, 12-13.

137 Ruth Wasem, Cuban Migration to the United States: Policy and Trends, Congressional Research Service Report R40566 (2 June 2009), 4.

${ }^{138}$ Newland, 77. Also in relation to the 2004 period, Frelick notes that of an initial group of 905 Haitains interdicted, only three passed a 'shout' test, and all of those failed a 'credible fear' screening on board: Bill Frelick, "AAbundantly Clear': Refoulement" Georgetown Immigration Law Journal 19 (2005): 245, 246. 
The practical limitations to extraterritorial processing are significant in part 2 because a feature of United States approach is that the Coast Guard is permitted to interdict even within United States territorial waters. The reason for allowing this form of interdiction is that, under the so-called 'wet foot/ dry foot' theory, it is only upon reaching shore that the protections of the Immigration and Nationality Act 1952 apply. ${ }^{139}$ The difficulty is that international law guarantees against non-refoulement must be taken to apply at least within territorial waters. Where interdiction occurs within territorial waters, the justification for United States policy must be that the system of extraterritorial processing on its own is sufficient to meet non-refoulement obligations. The evidence for that must be considered weak, however.

In one period - May 1992 to May 1994 - the United States openly returned migrants to Haiti, after interdiction on the high seas, without permitting a claim for protection. This was in response to a large outflow and the exhaustion of the available detention space at Guantánamo Bay. It was this phase of its interdiction policy which led to the Supreme Court's decision in Sale in 1993, in which it held that neither the Immigration and Nationality Act 1952 nor Article 33 of the Geneva Convention constrained return from international waters. ${ }^{140}$ In relation to Article 33, the Supreme Court's conclusion, based on an analysis of its language and of the negotiating history, was that the phrase "No Contracting State shall ... return ('refouler')" only covered someone's who was being turned away from the state's territory.

While the motivation for the United States interdiction programme has been the prevention of irregular migration, that objective has throughout had a significant legal component. In the period prior to the decision to introduce interdiction in 1981, the US immigration authorities had faced successful legal challenges to attempts both at mass refusals of asylum to Haitians, and at their mass expulsion. ${ }^{141}$ That litigation led directly to the proposal for interdiction in

139 For the legal opinion setting out this interpretation, see Department of Justice, "Immigration Consequences of Undocumented Aliens' Arrival in United States Territorial Waters” (13 October 1993), available at http://www.usdoj.gov/olc/nautical.htm (accessed 3 November 2009).

140 Sale v Haitian Centers Council 509 US 155 (1993).

${ }_{141}$ The litigation is discussed in Naomi Flink Zucker, 'The Haitians versus the United States: The Courts as Last Resort," Annals of the American Academy of Political and Social Science 467 (1983): 151. The key decision was Haitian Refugee Center v Civiletti, 503 F Supp 442 (Southern District of Florida, 2 July 1980), affirmed by 676 F2d 1023 (5th Circuit of Appeals, 14 May 1982). 
the July 1981 report of a presidential task force on immigration and asylum. According to the report:

The purpose of an interdiction program would be both to deter directly further unlawful migration by expeditiously returning migrants to Haiti, and incidentally, to curtail the flow of aliens into administrative and judicial proceedings in the United States. Although required by the UN Protocol and Convention to adjudicate refugee claims prior to returning a claimant to his homeland, if interdiction occurs outside of US territorial waters, the determination would not be governed by the Immigration Act. ${ }^{142}$

Interdiction continues to remain preferable from the authorities' perspective. While the mechanism of 'expedited removal' (discussed above) was extended in 2002 to those arriving irregularly by sea, it remains subject to the possibility to claim asylum. ${ }^{143}$ In addition, those who have reached the United States are likely to find it easier to indicate a protection need - and thereby to start the process than those who have been interdicted. Moreover those who succeed in an asylum claim will be able to stay in the United States, whereas those who succeed extraterritorially are likely to be resettled in another country.

\section{Australia's 'Pacific solution'}

United States policies of interdiction and extraterritorial processing have provided a model for other states in framing a response to irregular migration by sea. This was most obviously true of Australia in the period of the Howard Government's 'Pacific solution' from 2001 to 2007 - a story discussed in detail by Susan Kneebone in this collection. ${ }^{144}$ The 'Pacific solution' mainly concerned vessels arriving from Indonesia, and typically involved migrants with plausible claims to protection as refugees, and who mainly came from Afghanistan, Pakistan and Sri Lanka. The strategy began with a much-discussed incident in August-September 2001: when the Tampa, a Norwegian commercial vessel, entered Australian waters in order to disembark 433 Afghan migrants - which it had previously rescued - at Christmas Island, it was boarded by Australian troops, who ultimately transferred the migrants to a naval vessel, which took them for processing in Nauru. ${ }^{145}$

\footnotetext{
${ }_{142}$ Quoted in Flink Zucker, 159.

143 “Notice Designating Aliens Subject to Expedited Removal”, 67 Federal Register 68924 (13 November 2002).

144 See also Penelope Mathew, "Legal Issues Concerning Interception" Georgetown Immigration Law Journal 17 (2003): 221 and Tara Magner, "A Less than 'Pacific' Solution for Asylum Seekers in Australia" International Journal of Refugee Law 16 (2004): 53.

145 For an official summary, see Parliament of Australia, Senate Select Committee on a Certain Maritime Incident: Main Report (23 October 2002), 1-3. For an international law analysis, see Richard Barnes, "Refugee Law at Sea" International and Comparative Law Quarterly 53 (2004): 47.
} 
The core of the 'Pacific solution' approach was extraterritorial processing in 2 Nauru and on Manus Island in Papua New Guinea. Protection claims by these persons were at first assessed by the UNHCR, and then by the Australian authorities. ${ }^{146}$ Crucially, however, these procedures did not include any avenue of legal challenge before an Australian tribunal or court. ${ }^{147}$ By mid-2006, 1547 persons had been processed in the two locations, of whom 482 had returned to their countries of nationality and 1062 had been resettled - "mainly" to Australia and New Zealand. ${ }^{148}$ In 2007, a further 90 persons were transferred to Nauru, of whom 81 were found to be entitled to protection, and were allowed to settle in Australia by the new Rudd Government in December 2007. ${ }^{149}$

The 'Pacific solution' was brought to an end by the Rudd Government soon after it came to power in November 2007. The new government's decision to do so was motivated in part by the transport and detention costs associated with processing in Nauru and Papua New Guinea. ${ }^{150}$ Since early 2008, those interdicted at sea, or who reach an excised island, have instead been taken for 'offshore' processing on Christmas Island. ${ }^{151}$ Access has been given to lawyers and interpreters, and there is the prospect of settlement in Australia if an applicant is successful. Nevertheless, the fact that Christmas Island is 'excised' from the migration zone means that their claims continue to be assessed outside of the standard legal mechanisms governing asylum claims. ${ }^{152}$

Interdiction at sea has been central to Australia's control policy throughout the entire period since the Tampa incident in 2001. The legal basis for interdiction is to be found in legislation adopted in 1999 in response to unauthorised boat arrivals that year. ${ }^{153}$ The 1999 legislation sought to make maximum use of

146 Susan Kneebone, “The Pacific Plan: The Provision of 'Effective Protection'?” International Journal of Refugee Law 18 (2006): 696, 715.

147 This is the effective consequence of the excision of offshore islands from the coverage of the Migration Act 1958: see section 5(1) of the 1958 Act, as amended by the Migration Amendment (Excision from Migration Zone) Act 2001 and the Migration Amendment Regulations 2005 (No 6), SLI 2005 No 171. For a discussion, see Ernst Willheim, “'Don't Bother Knocking”: Australia's Response to Asylum Seekers" in The Challenge of Asylum to Legal Systems, ed Prakash Shah (London, Cavendish: 2005), 252-253.

148 Department of Immigration and Multicultural Affairs, Annual Report 2005-06, p 176. Two others remained on Nauru, while a further migrant died of natural causes.

149 "Pacific Solution ends but tough stance to remain", Sydney Morning Herald, 8 December 2007.

150 "Refugee status given to Burmese; Swift end to "Pacific Solution" The Age, 10 December 2007.

151 "Government Denies Back Flip on Island Excision”, The Age, 21 February 2008.

152 See the discussion in Susan Kneebone's chapter in this volume.

153 Sections 245A-245H of the Migration Act 1958, inserted by the Border Protection Legislation Amendment Act 1999 and Andreas Schloenhardt, "Australia and the Boat People: 25 Years of Unauthorised Arrivals" University of New South Wales Law Journal 23 (2000): 33, 52-53. 
the possibilities given by international law for interdiction outside of territorial waters. ${ }^{154}$ In particular, it permitted the boarding of foreign vessels in Australia's contiguous zone, and of vessels without nationality on the high seas, and allowed the 'hot pursuit' of a vessel which left the contiguous zone for the high seas. In practice, interdiction within territorial waters and the contiguous zone was the preferred option in interdiction operations after the Tampa incident in $2001 .{ }^{155}$ By contrast, the subsequent approach - against the background a policy of processing on Christmas Island - has included greater willingness to engage in operations beyond the 24- mile limit. ${ }^{156}$

During the period immediately after the Tampa incident, the Australian authorities also sought to tow vessels and their passengers back to Indonesia. The statutory basis for these 'tow backs' was in legislative amendments adopted at that time, which allowed persons on board detained vessels to be taken "to a place outside Australia." ${ }^{157}$ Four of the 12 vessels detected after the Tampa during 2001 in or near Australian waters were successfully towed back, and there was one unsuccessful attempt. ${ }^{158}$ There was also at least one subsequent 'tow back' involving the Minasa Bone - in November 2003. ${ }^{159}$ Tow-backs were also threatened in April 2006, after a group of migrants arrived from the Indonesian territory of West Papua successfully claimed asylum. ${ }^{160}$

Australia's 'Pacific solution' again shows how the desire to avoid international and domestic legal guarantees can lead to extraterritorial immigration control practices. The occasional tow-backs to Indonesia were plainly motivated by the desire to avoid any legal responsibility for asylum seekers and recognised refugees.

${ }^{154}$ For a discussion of the law of the sea and migration control see the contribution by Richard Barnes to this volume.

155 See the account of the Australian Defence Forces' operating procedures in 2001 in Select Committee on a Certain Maritime Incident: Main Report, 25-27.

156 This is apparent for example from these recent press releases of the Minister for Home Affairs: "Border Protection Command Boards Vessel", 12 September 2009 (rescue, 82 miles off Ashmore Island) and "Border Protection Command Boards Vessel”, 17 September 2009 (assistance, 78 miles off Darwin).

157 Migration Act 1958, section 245F(9), as amended by the Border Protection (Validation and Enforcement Powers) Act 2001, Schedule 2. This amendment was intended to address the lack of a statutory basis for the transfer of interdicted persons to sites of extraterritorial processing. In litigation concerning the Tampa incident, this gap had been overcome only by the debatable finding that the state's actions were protected by a prerogative power to exclude aliens: see Ruddock v. Vadarlis [2001] FCA 1329, discussed in Susan Kneebone's chapter.

158 Jessica Morris, “To Deter and Deny: Australia and the Interdiction of Asylum Seekers" Refuge 21: 4 (2003): 35, 46.

159 "Minasa Bone Returns to Indonesia”, Minister for Foreign Affairs press release, 9 November 2003.

160 “Navy May Force Papuan Boats Back: Minister”, Sydney Morning Herald, 6 April 2006. 
More importantly, Australia's introduction of extraterritorial processing was 2 designed to avoid rights of access to domestic courts. Much as with the United States policies, the Australian strategy between 2001 and 2007 implied a restrictive interpretation of international law obligations - that it permitted individuals to be taken from inside the territory or territorial waters to a site of extraterritorial processing, and that limited procedural guarantees were possible while there.

\section{European interdictions}

A final set of interdictions at sea to consider are those aimed at migrants seeking to reach two of the Southern member states of the European Union - Italy and Spain. ${ }^{161}$ The first systematic attempts at immigration control at sea in Europe were Italian interdiction operations from 1997, in response to the arrival of an estimated 30,000 migrants by sea from Albania in January-April that year. ${ }^{162}$ Albania's authorisation for the interdiction and return of these vessels was given an agreement in March 1997 between the two states. In practice, interception occurred in both international and Italian waters, while the Albanian authorities co-operated through disruption activity aimed at preventing boats from departing. ${ }^{163}$ Even after 1997, significant numbers of arrivals from Albania continued to be detected in Puglia: more than 106,000 in the five years 1998-2002, with a peak of 46,481 in $1999 .{ }^{164}$ These migration flows largely came to an end by 2002, ultimately because of an improvement of economic and social conditions in Albania, itself linked to Italian support for Albanian development. ${ }^{165}$

The second zone of large-scale sea migration to Italy has been from North Africa towards Lampedusa and Sicily. In the early 1990s, these arrivals were made up of North Africans departing from Tunisia, but that flow ceased around 1998 as a result of disruption activity in Tunisia, against a background of co-operation between the two states. ${ }^{166}$ From 2002, larger numbers, mainly from sub-Saharan

161 There have also been claims that Greek and Maltese coastal authorities have engaged in interdiction practices: see Human Rights Watch reports Stuck in A Revolving Door; Iraqis and other Asylum Seekers and Migrants at the Greecel Turkey Entrance to the European Union (November 2008), 41-47 and Pushed Back, Pushed Around: Italy's Forced Return of Boat Migrants and Asylum Seekers, Libya's Mistreatment of Migrants and Asylum Seekers (September 2009), 38-39. As these states have not adopted a policy of interdiction, however, they are not considered here.

162 See the chapter by Alessia di Pascale in this volume and Derek Lutterbeck, "Policing Migration in the Mediterranean" Mediterranean Politics 11 (2006): 59, 62.

163 Paola Monzoni, "Sea-Border Crossings: The Organization of Irregular Migration to Italy" Mediterranean Politics 12 (2007): 163, 172.

164 Ibid, 167.

165 See the chapter by Alessia di Pascale in this collection.

166 Monzoni, 177. 
African countries, began to arrive on the longer sea route from Libya. ${ }^{167}$ In total, 141,245 migrants were recorded as arriving by sea in Lampedusa or Sicily between 2002 and 2008, with a peak of 34,600 in 2008. ${ }^{168}$

Until early 2009, the Italian coastal authorities generally permitted migrants to land, and processed any resulting asylum claims, prior to attempts at repatriation. ${ }^{169}$ This approach was however the subject of a dramatic change on 6 May 2009, as the Italian coastal authorities began intercepting migrants in international waters off Lampedusa, taking them on board, and returning them to Libya. ${ }^{170}$ By August 2009, it was reported that around 14 such operations had taken place, involving around 800 migrants. ${ }^{171}$ The background to these developments was an agreement reached between Italy and Libya in December 2007 which provided for "joint patrols" off Libya, and for the provision of up to six vessels by Italy to the Libyan coast guard. ${ }^{172}$ The 2007 agreement did not, however, expressly provide for the return of those who were closer to Italian territory than to Libya, and neither did it appear to contemplate return by Italian-only operations. These possibilities appear instead to be based on an unpublished "implementation protocol", agreed when the Italian Interior Minister, Roberto Maroni, visited Tripoli in February 2009. ${ }^{173}$ The new strategy has led to a reduction in arrivals from Libya, which fell by $90 \%$ between May-August 2008 (over 15,000) and May-August 2009 (1,400). ${ }^{174}$ The strategy has been criticised for the lack of investigation of possible claims to protection - or even the nationalities - of those returned to Libya, particularly given the absence of an asylum mechanism in Libya. ${ }^{175}$

\footnotetext{
167 Ibid, $177-178$.

${ }^{168}$ For individual years to 2007, see Paola Monzoni, Il Traffico di Migranti per Mare verso l'Italia: Sviluppi recenti (2004-2008), (CESPI working paper 43/2008), 7. For 2008, see Frontex, Annual Report 2008, 12.

169 There were some examples of presumed collective repatriation from Lampedusa to Libya in 2004 and 2005: see the chapter by Alessia di Pascale.

${ }^{170}$ UNHCR, "UNHCR deeply concerned over returns from Italy to Libya," press release, 7 May 2009.

171 "Respinti finora 800 extracomunitari: Quasi tutti avevano diritto d' asilo", Repubblica, 25 August 2009.

172 The Italian text of the agreement can be found at http://www.ilvelino.it/archivio/documenti/ allegato_documento_621.pdf (accessed 3 November 2009).

${ }^{173}$ For this conclusion, see Fulvio Vassallo Paleologo, "Dopo i migranti Maroni respinge lo stato di Diritto", 14 September 2009, available at http://www.meltingpot.org/articolo14803 .html (accessed 3 November 2009).

${ }^{174}$ Minister dell'Interno, "Immigrazione irregolare dalla Libia: Diminuiti dal 90\% gli sbarchi," press release 9 September 2009.

175 See generally Human Rights Watch, Pushed Back, Pushed Around (September 2009), above.
} 
Spain has also addressed recent migration by sea through co-operation in con2 trol with states of departure - a phenomenon examined in Paula García Andrade's contribution to this collection. Significant levels of irregular migration across the Strait of Gibraltar had occurred in the 1990s, with a peak in 2001, when 14,405 migrants were detained having arrived by sea from Morocco. ${ }^{176}$ Spain's response included an agreement in 2003 with Morocco which permitted joint patrols in Moroccan waters. Even still, many migrants have continued to be detected on this route, with only a gradual decline from the 9,788 detained in 2003 to 4,243 in 2008. ${ }^{177}$

Spain has responded in a similar fashion to arrivals to the Canary Islands. ${ }^{178}$ In the 1990s, there were a small number of arrivals there, mainly coming directly from the closest points on the African continent in Morocco and Moroccancontrolled Western Sahara. From 2000 onwards, the numbers started to increase, and generally involved sea journeys of several hundred miles from departure points further south. In the years from 2001 to 2008, the total number of arrivals to the Canary Islands was 89,851 , with a peak of 31,678 in $2006 .{ }^{179}$ Spain's attempted solution was again to develop joint patrol arrangements with countries of departure. As García Andrade's explains, arrangements of this kind have been entered into with Mauritania and Senegal (both 2006), Cape Verde (2007), Gambia, Guinea Bissau and Guinea Conakry (all 2008). Here too, substantial migration has nevertheless continued. In 2008, while 5,969 persons were reported diverted back to Mauritania and Senegal, 9,181 migrants arrived by sea in the Canary Islands, which was roughly the average for the period from 2001. ${ }^{180}$

Legal factors have played a significant role in the Italian and Spanish adoption of strategies of interdiction, rather than allowing migrants to arrive, and then processing them as irregular entrants. As elsewhere, these strategies have partly been about avoiding responsibility for asylum claims. This appears especially relevant in the case of Italy: it has been reported that $75 \%$ of arrivals in Lampedusa in 2008 made applications for asylum, and that around $50 \%$ of these were

${ }^{176}$ For the period up to 2000, see Lutterbeck, 62-63. Figures for individual years from 2001 are in Asociación Pro Derechos Humanos de Andalucía (APDHA), Derechos Humanos en la Frontera Sur 2008 (2009), 93. These are based on official data, published most recently in Ministerio del Interior, "Balance de la Lucha Contra la Inmigración Ilegal 2008", available from http://www .mir.es/DGRIS/Balances (accessed 3 November 2009).

177 APDHA, 93.

178 For a summary of these migration flows, see Jørgen Carling, "Unauthorized Migration from Africa to Spain" International Migration 45 (2007): 3, 24-26.

179 APDHA, 93.

180 Frontex, "HERA 2008 and Nautilus 2008 Statistics", news release 17 February 2009 and APDHA, 93. 
granted some form of protection. ${ }^{181}$ In the case of Spain, by contrast, it appears that irregular migrants arriving by sea very often do not claim asylum: for example, only 1377 applications for refugee status were made in the Canary Islands between 2006 and 2008, which was only 2.6\% of the number of arrivals there over the same period. ${ }^{182}$

For the Italian and Spanish authorities, domestic legal limits to detention for the purposes of identification and expulsion are a further reason for interdiction strategies. In Italy, a change in the law in 2002 increased the maximum period that an irregular migrant could be detained from 30 days to 60 days, after which they had to be released and ordered to leave the territory. ${ }^{183}$ Spain has a similar system, with a maximum period of detention is 40 days. ${ }^{184}$ At the time of writing, both countries have recently taken steps to increase these limits. In Italy, the maximum detention period was increased to 180 days by legislation adopted in July $2009 .{ }^{185}$ Meanwhile, in Spain, a government bill is before parliament which would increase the maximum detention period to 60 days. ${ }^{186}$

A final point with respect to Italian and Spanish interdictions concerns Frontex (the European border agency), which is analysed in detail in the chapter by Anneliese Baldaccini in this volume. Frontex has been involved in the delivery of Spanish-led interdiction operations off North and West Africa. ${ }^{187}$ It also runs operation NAUTILUS from Malta, which may be thought to make Italian interdiction more likely by identifying or deflecting migrants vessels - even if Frontex claims no direct involvement in Italy's "diversion activities". ${ }^{188}$ Indeed, prior to Italy's agreements with Libya, Frontex had itself sought to negotiate a joint arrangement to enable interdiction. ${ }^{189}$ While interdiction is ultimately a national

181 UNHCR, "UNHCR concerned over humanitarian situation in Lampedusa, Italy” press release, 23 January 2009.

182 The application data is in UNHCR, "Refugee Protection and International Migration: A review of UNHCR's role in the Canary Islands, Spain” (April 2009), para 23.

183 Article 14(5) of the 'Single Text' on immigration (Legislative Decree no. 286 of 25 July 1998), as amended by Law no 189 of 30 July 2002.

184 Article 62(2) of the Organic Law 4/2000 of 11 January 2000 on the rights and liberties of foreigners in Spain.

185 Amendment to Article 14(5) by Law no 94 of 15 July 2009.

186 See Boletín Oficial de las Cortes Generales no 31-1, 1 July 2009.

187 See the brief information on operations HERA, MINERVA and INDALO in Frontex, Annual Report 2008, 40.

188 Ibid, for brief information on operation NAUTILUS. Frontex's statement in relation to Italian interdiction is "Frontex not involved in diversion activities to Libya", press release 21 September 2009.

189 Frontex, Frontex-Led EU Illegal Immigration Technical Mission to Libya 28 May-5 June 2007, especially para 2.5, available at http://www.statewatch.org/news/2007/oct/eu-libya-frontexreport.pdf (accessed 3 November 2009). 
policy choice of Italy and Spain, it is clear that Frontex has increased the possibil2 ity for it to occur.

The proliferation of extraterritorial immigration control practices, particularly over the past two decades, can partly be explained by reference to factors other than legal guarantees. We have seen in this chapter that in many circumstances such as preclearance operations, or visas - the advantages to travellers can be a reason for such controls, because their journeys are not held up on arrival, or because they gain access a broader range of destinations. Developments in digital technology - including biometrics - are also relevant, in that they permit disparate immigration decision-makers to communicate with central authorities, and to check databases, in the home state.

It is also clear that extraterritorial control leads to a legal regime which is favourable to intended destination states. By intervening before arrival, a destination state will hope to avoid the legal and logistical problems associated with returning someone to their state of nationality or departure. Specifically, return may be difficult to effect unless the individual's nationality and/ or travel route can be identified, and unless there are arrangements for readmission with the state in question. ${ }^{190}$ In addition, this chapter has shown how strategies of extraterritorial control enable destination states to free themselves from legal guarantees otherwise available to migrants. These strategies generally set out to avoid international law obligations concerning non-refoulement. They also typically seek to avoid domestic legal guarantees, such as rights of appeal and restrictions on detention, which are either freestanding, or which implement the principle of non-refoulement. Some combination of all these elements - avoidance of problems with return, non-refoulement obligations and domestic guarantees - has played a role in almost every initiative taken since the mid-1980s: the expansion of visa requirements, the introduction of carriers' obligations, the introduction of juxtaposed controls for travel to the United Kingdom, and strategies of interdiction at sea by the United States, Australia, Italy and Spain.

If we assume that forms of extraterritorial immigration control are likely to continue, is there a normative basis for the restoration of lost legal guarantees to those who face extraterritorial action? One concrete question concerns the

190 On the international legal framework governing return, see Gregor Noll, "Return of Persons to 
legal position of persons refused a visa or permission to travel, or who are prevented from embarking. In normative terms, it is clear that any substantive rights of such persons - particularly those deriving from fundamental rights provisions or from national immigration law - ought to remain applicable in extraterritorial decision-making. Otherwise, the state will have escaped its legal obligations to individuals by the device of changing the location of decision-making. In addition, respect for the rule of law in these cases requires that effective legal procedures be available against negative decisions. ${ }^{191}$ That this is not a utopian suggestion is shown by the provision made for appeals within the European Union's Visa Code, discussed above. Indeed, the very technological developments which support remote decision-making also strengthen the practical possibility to provide legal advice and legal procedures to those refused immigration permission extraterritorially.

A second concrete question concerns the applicability of the principle of nonrefoulement where control takes place extraterritorially. A number of developed states - including the United States, the United Kingdom and Italy - deny that duties of international protection have any extraterritorial reach. ${ }^{192}$ The legal response to these developments has been to insist that international law guarantees of non-refoulement do apply extraterritorially. The reasoning in Sale has been criticised - including by den Heijer in this volume - on the grounds that Article 33 refers to return/refoulement "in any manner whatsoever", and that it should be interpreted in light of its humanitarian purpose. ${ }^{193} \mathrm{~A}$ parallel argument has been developed with respect to human rights instruments - in particular, Article 3 of the European Convention on Human Rights - that a state's jurisdiction and responsibility arise from effective control over an individual or place, rather than from territory. ${ }^{194}$ Writing in this volume, Anja Klug and Tim Howe bring these lines of analysis together, through the application of the expansive test of

\footnotetext{
191 See generally Jorrit Rijpma and Marise Cremona, "The Extra-Territorialisation of EU Migration Policies and the Rule of Law" EUI Working Papers, Law 2007/01.

192 The conduct of the United States and Italy reflecting this position is discussed in the text, above. In the case of the United Kingdom, the narrow reading of Article 33 in Sale (above) was approved by the House of Lords in $R$ v. Immigration Officer Prague Airport, ex parte European Roma Rights Centre [2004] UKHL 55, in relation to a temporary preclearance operation by UK immigration authorities at Prague airport.

193 See in particular UNHCR Advisory Opinion on the Extraterritorial Application of NonRefoulement Obligations under the 1951 Convention relating to the Status of Refugees and its 1967 Protocol (2007) and Andreas Fischer-Lescao, Tillmann Löhr and Timo Tohidupur, "Border Controls at Sea: Requirements under International Human Rights Law and Refugee Law" International Journal of Refugee Law 21 (2009): 256, 265-271.

194 Fischer-Lescao, Löhr and Tohidupur, 272-277.
} 
responsibility in international human rights law to the interpretation of Article 2 33 of the Geneva Convention.

It is clear that the rejection of any responsibility by states acting extraterritorially is normatively unsustainable. This is for the obvious reason that that position would give states an incentive to manufacture a vacuum in international protection. In other words, they would be free to create a situation in which an individual in principle qualified for international protection, but no state was responsible for its provision.

The opposite proposition - the application of the non-refoulement principle to all extraterritorial immigration action - may however also be too broad. One situation in which this proposition ought to be qualified is where there is a 'territorial' state which could itself offer an acceptable level of protection. The logic of non-refoulement does not require a state acting extraterritorially to protect individuals on the territory of another state, where that state could itself do so. In particular, in such circumstances there may not be a causal link between the actions of the destination state and the possible refoulement. ${ }^{195}$ It may therefore be best to treat extraterritorial responsibility for non-refoulement as the default position, applicable only where there is no territorial state which can itself offer effective protection.

Secondly, the extension of responsibility for non-refouelement to every extraterritorial action posed difficulties in the context of irregular migration by sea. If all extraterritorial action by states gives rise to legal responsibility, states will have an incentive not to engage in safety-oriented surveillance, or in rescue operations particularly where several states are potentially responsible for surveillance and rescue. Alternatively - to the extent that safety-oriented surveillance and rescue remain effective - migrants will have an incentive to engage in risky journeys, in the hope of benefiting from non-refoulement after rescue. A comprehensive humanitarian solution to the dilemmas posed by irregular migration by sea must include both respect for non-refoulement, and also respect for the safety of human life. Here too, it may be preferable to treat extraterritorial responsibility as the default position, subject to context-specific arrangements, which respect nonrefoulement and provide for the sharing of protection and safety obligations among states.

195 For a discussion of the implications of a causation requirement for extraterritorial decision- 
